\title{
Reproductive performance of Santa Inês ewes fed protected fat diet
}

Ricardo Lopes Dias da Costa(1), Reginaldo da Silva Fontes ${ }^{(2)}$, Eduardo Antonio da Cunha ${ }^{(1)}$, Mauro Sartori Bueno(1), Celia Raquel Quirino(2), Vivian Alves Costa Afonso(3), Walter Guimarães Otero(4), Luis Eduardo dos Santos ${ }^{(1)}$ and Ângelo José Burla Dias ${ }^{(2)}$

(1)Agência Paulista dos Agronegócios, Instituto de Zootecnia, Rua Heitor Penteado, no 56, CEP 13460-000 Nova Odessa, SP, Brazil. E-mail: rldcosta@apta.sp.gov.br, cunha@iz.sp.gov.br, msartori@iz.sp.gov.br, lesantos@iz.sp.gov.br (2Universidade Estadual do Norte Fluminense, Laboratório de Melhoramento e Reprodução Animal, Avenida Alberto Lamego, no 2.000, CEP 28013-600 Campos dos Goytacazes, RJ, Brazil. E-mail: rfontes@uenf.br, crq@uenf.br, angelopecgen@yahoo.com.br ${ }^{(3)}$ Centro Paula Souza, Escola Técnica Agrícola Dr. José Coury, Caixa Postal 37, CEP 13390-000 Rio das Pedras, SP, Brazil. E-mail: vivianveterinaria@hotmail.com ${ }^{(4)}$ Nestlé Purina, Rua Servidão Knussen, no 131, CEP 88048-460 Florianópolis, SC, Brazil. E-mail: wpotero@yahoo.com.br

Abstract - The objective of this work was to evaluate the reproductive performance of Santa Inês ewes fed a diet supplemented with protected fat. Intervals from lambing to first clinical estrus and to conception, conception rate, prolificacy, live weight and body condition were determined. After lambing, 60 ewes and their offsprings were weighted and randomly assigned to three treatments, based on age, body weight and number of born lambs. Treatments consisted of: control diet, or control diet plus $30 \mathrm{~g}$ of protected fat, from lambing to day 25 of post-lambing (Sup25), or to day 60 of post-lambing (Sup60). Out of 60 evaluated ewes, 93.3\% returned to estrus, and $74.5 \%$ got pregnant, with $73.53 \%$ lambing rate and 196.5 days lambing interval. The average periods from lambing to first estrus were 32.4, 27.2 and 35.5 days for ewes fed the control diet, Sup25, and Sup60, respectively. The intervals from lambing to conception were 45.2, 46.5 and 45.2 days, and the supplemented diets did not show differences in comparison to the control diet. Supplementation with protected fat to well-nourished Santa Inês ewes does not improve their reproductive performance.

Index terms: Ovis aries, conception rate, estrus, lambing interval, nutrition.

\section{Desempenho reprodutivo de ovelhas Santa Inês alimentadas com dieta com gordura protegida}

\begin{abstract}
Resumo - O objetivo deste trabalho foi avaliar o desempenho reprodutivo de ovelhas Santa Inês alimentadas com dieta suplementada com gordura protegida. Os intervalos do parto ao primeiro estro clínico e à concepção, a taxa de gestação, a prolificidade, o peso vivo e a condição corporal foram determinados. Depois do parto, 60 ovelhas e seus cordeiros foram pesados e distribuídos aleatoriamente em três tratamentos com base na idade, peso corporal e número de cordeiros nascidos. Os tratamentos consistiram de dieta controle ou da dieta controle mais $30 \mathrm{~g}$ de gordura protegida, do parto aos 25 dias pós-parto (Sup25), ou aos 60 dias pós-parto (Sup60). Das 60 ovelhas avaliadas, $93,3 \%$ retornaram ao estro, e 74,5\% ficaram prenhes, com taxa de parição de 73,53\% e intervalo de parto de 196,5 dias. O período médio do parto até o primeiro estro foi de 32,4, 27,2 e 35,5 dias, para as ovelhas alimentadas com a dieta controle, Sup25 e Sup60, respectivamente. Os intervalos do parto até a concepção foram de 45,2, 46,5 e 45,2 dias, e as dietas com suplementação não apresentaram diferenças em comparação ao tratamento controle. A suplementação com gordura protegida para ovelhas da raça Santa Inês, bem nutridas, não melhora seu desempenho reprodutivo.
\end{abstract}

Termos para indexação: Ovis aries, taxa de concepção, estro, intervalo de parto, nutrição.

\section{Introduction}

Inadequate nutrient intake after lambing is a common cause of reproductive performance reduction, due to the decrease of fertility rates. This happens because of the ovarian activity inhibition after conception and in post-lambing period. The inhibition occurs as a result of changes in the endocrine, neural and metabolic mechanisms, which include alterations in the pituitary secretion pattern (gonadotropins), progesterone production by the corpus luteum, with greater sensitivity of the hypothalamic-pituitary axis to steroid hormones, which influence the ovarian activity (Short \& Adams, 1988).

Amongst many factors affecting the reproductive performance of ruminants, energy has the greatest impact. There is interest on fat supplementation in ruminant diets since it increases energy density, and can supplement the diets with beneficial fatty acids, 
which may improve reproductive rates. Effects of supplementation with some sources of fatty acids on reproduction are controversial. Dietary polyunsaturated fatty acids (PUFAs) provide the body with energy, contribute with structural components to cell membranes and also act as precursors for prostaglandin (PG) synthesis. Supplementation with linoleic acid (LA, C18:2) and linolenic acid (LNA, C22:3) in cattle diet, in pre and post-partum periods, can improve reproductive rates (Lucy et al., 1992).

Within the body, linoleic acid can be metabolized into arachidonic acid (AA; 20:4n-6; Kinsella et al., 1990; Bezard et al., 1994) and produce two series of prostaglandins (PGF), including $\mathrm{PGF}_{2 \alpha}$ and $\mathrm{PGE}_{2}$ (Smith et al., 1991). Excessive intake of linoleic acid may decrease the production of progesterone, increase $\mathrm{PGF}_{2 \alpha}$, accelerate uterine involution and anticipate the fertile estrus with the possibility of an earlier conception. Linolenic acid can be transformed into eicosapentaenoic acid (EPA) and docosahexaenoic acid (DHA) (Madsem et al., 1999). The EPA (C20:5n-3) and DHA (C22:6n-3) act as competitive inhibitors during metabolism of arachidonic acid on the synthesis of prostaglandins. In some studies with dairy cows, the presence of these fatty acids in the diet inhibited the synthesis of $\mathrm{PGF}_{2 \alpha}$ by uterine endometrium (Thatcher et al., 1997).

However, dietary PUFA can be hydrolyzed into the rumen by bacterial lipases releasing free fatty acids that can undergo extensive biohydrogenation by microorganisms, and their chemical structure can be altered by saturation (Annison et al., 2003). Rumen bypass fatty acids (protected fat) can be used for sheep supplementation, in order to prevent their biohydrogenation, and reach the intestines with pre-formed long-chain fatty acids to be absorbed and metabolized by the animal. Fatty acids protected with calcium salt are the most common form of protected fat supplement for ruminant diets.

Santa Inês is a hair sheep and one of the most reared breeds in Brazil. According to Araújo et al. (2009), Santa Inês ewes are prone to cycle and conceive soon after lambing, with an interval of eight months between lambings.

The objective of this work was to evaluate the reproductive performance of Santa Inês ewes fed a diet supplemented with protected fat on the post-lambing period.

\section{Materials and Methods}

The experiment was carried out at Instituto de Zootecnia, in Nova Odessa county, SP, Brazil $\left(22^{\circ} 42^{\prime} \mathrm{S}\right.$, $\left.47^{\circ} 18^{\prime} \mathrm{W}\right)$, with a Cwa climate type, according to Köppen's classification. The average annual rainfall is approximately $1,270 \mathrm{~mm}$ (Santos et al., 1977). The experiment was performed between April and July.

Pregnant ewes, kept on pasture of Panicum maximum Jacq. cv. Aruana or Tanzania (Guinea grass), received a supplementation of corn silage ad libitum and a concentrate mixture (400 g per day) of $16 \%$ crude protein and $80 \%$ of total digestible nutrient (TDN) throughout pregnancy and in the final third of it.

After lambing, 60 ewes were weighted, evaluated for body condition score, and assigned to three treatments (20 ewes each), according to their age, body weight and number of born lambs, in a completely randomized design. Ewes and their lambs were kept in three collective pens, according to the treatment: control, no supplementation of protected fat; Sup25, supplementation with $30 \mathrm{~g}$ per head per day with protected fat Megalac E, (Química Geral do Nordeste S.A., Nova Ponte, MG, Brazil), until the $25^{\text {th }}$ day of post-lambing; Sup60, supplementation with $30 \mathrm{~g}$ per head per day with protected fat until weaning at $60^{\text {th }}$ day of post-lambing.

Fatty acids profile of protected fat was as follows: 40-42\% linoleic acid; $2.7-3.0 \%$ linolenic acid; $32.3 \%$ oleic acid; $16.3 \%$ palmitic acid; and $4.8 \%$ of stearic acid.

The average prolificacy of the 60 ewes was 1.3 lambs per ewe, with a total of 78 born lambs, 42 single and 18 twins; and the mortality rate was $3.9 \%$ (three lambs).

The nursing ewes were fed with maize silage and $800 \mathrm{~g}$ per animal per day of concentrate mixture. Chemical analysis of the concentrate mixture, without protect fat, was: dry matter (DM\%), 87.6; crude protein $(\mathrm{CP} \%), 18.2$; ether extract (EE\%), 3,2; neutral-detergentfiber(NDF\%) 18.8; acid-detergentfiber (ADF\%) 11.2. The chemical analysis of the concentrate mixture with protect fat was: $\mathrm{DM} \%, 86.8 ; \mathrm{CP} \%, 19.1$; $\mathrm{EE} \%, 6.96$; NDF\%, 17.6; ADF\%, 13.4. The ewes were kept with their lambs in collective pens until 15 days after lambing. After this period, the ewes were separated from their lambs during the day, and taken to pasture, while the lambs stayed in the pens with access to creep rations with $20 \% \mathrm{CP}$ and $82 \%$ TDN. In the morning, the dams were fed half of the daily concentrate ration, 
and taken to pasture to stay daylong with the rams. In the afternoon, the ewes were separated from the rams, brought to the pens, placed with their lambs and fed the remaining concentrate ration. The lambs were weaned at approximately 60 days of age, gathered in the same pen, and fed with maize silage and $500 \mathrm{~g}$ per animal per day of a concentrate mixture with $20 \% \mathrm{CP}$ and $82 \%$ of TDN.

Estrus detection was carried out daily, by visual observation performed by two observers, during the first 20 min after joining rams and ewes, and another 20 min during taking off the rams. Concurrently, two marker rams had their brisket smeared by a mixture of grease and red ink and were kept the whole day with a maximum of 30 ewes each; the ink on the back of the ewes' rumps characterized the receptiveness of females to males. These procedures were performed until the $75^{\text {th }}$ day after lambing.

Pregnancy diagnosis was performed with an ultrasound device with a linear $7.5 \mathrm{MHz}$ transrectal transducer Vet Scan 200, (Pie Medical, Maastricht, The Netherlands), thirty days after the last mating. Twenty ewes with 27, 24 and 27 lambs were allocated to control, Sup25 and Sup60 treatments, respectively.

The ewes were weighted (ELW) and evaluated for body condition score (BCS) in the following periods: in the morning, before feeding, at the time of lambing (ELW0, BCS0), and on days 15 (ELW15 and BCS 15), 30 (ELW30, BCS30), 45 (ELW45, BCS45) and 60 (ELW60, BCS60) post-lambing.

Estrus and mating were recorded for calculating the conception rate (CR) and the intervals from lambing to first clinical estrus (ILFE) and to conception (ILC), and from postpartum estrus to conception. Lambing rate (\%) and lambing interval (days) were also evaluated.

The interval from lambing to the first estrus, number of post-lambing estrus until conception, interval between estrus and interval between parturition were analyzed using the GLM procedure (SAS Institute,
1996), and the model considered treatments as fixed effects. The analysis of variance for ELW15, ELW30, ELW45 and ELW60 used ELW 0 and the litter size (the number of offspring produced at one birth by an animal) as covariables. The means were compared by SNK test, at $5 \%$ probability. The percentage of return to estrus $(\% \mathrm{RE})$ and pregnancy rate $(\mathrm{Pr})$ were analyzed by the chi-square test.

\section{Results and Discussion}

The nutrition supplements met the needs for maintenance and milk production in all treatments, and did not lead to weight loss (Table 1). There was no significant difference for ewe weights among treatments in the different periods after lambing. There was also no difference on body score conditions among treatments in the different periods after lambing (Figure 1). The values remained between 2.5 and 3 during the experimental period, which seemed to be adequate for nursing ewes. There was, however, a little increase in the average BSC0 compared with $\mathrm{BSC} 15$, probably due to an increase in food ingestion usually found in this setting, as a result of the augment of total rumen distension capacity and ending of the competition between nutrients ingested by dams and fetus. There was a decrease in BCS30 compared with BSC15, in all treatments, probably due to the lactation peak (Bencini \& Pulina, 1997).

The weight and body condition score patterns during ewes nursing period is in compliance with the pattern presented by Costa et al. (2007), that pointed out a small increase in these values immediately after lambing, and a slight decrease after lambing.

Energy and protein supplied by the diet was enough to satisfy the requirements for maintenance and lactation, according to the National Research Council (2007), as evidenced by the maintenance of adequate live weight and body condition score. The use of protected fat probably did not affect the intake of energy, as

Table 1. Means \pm standard deviations (SD) for ewe live weight ( $\mathrm{kg}$ ) at lambing (ELW0), and on days 15 (ELW15), 30 (ELW30), 45 (ELW45) and 60 (ELW60) after lambing, under protected fat supplementation treatments.

\begin{tabular}{lccccc}
\hline Treatment $^{(1)}$ & ELW0 & ELW15 & ELW30 & ELW45 & ELW60 \\
\hline Control & $50.82 \pm 9.9 \mathrm{a}$ & $52.03 \pm 10.4 \mathrm{a}$ & $52.11 \pm 10.3 \mathrm{a}$ & $51.98 \pm 9.3 \mathrm{a}$ & $52.06 \pm 10.5 \mathrm{a}$ \\
Sup25 & $49.87 \pm 9.3 \mathrm{a}$ & $51.31 \pm 9.9 \mathrm{a}$ & $51.19 \pm 7.8 \mathrm{a}$ & $52.17 \pm 8.6 \mathrm{a}$ & $51.96 \pm 8.5 \mathrm{a}$ \\
Sup60 & $51.07 \pm 7.2 \mathrm{a}$ & $53.08 \pm 7.4 \mathrm{a}$ & $52.73 \pm 7.1 \mathrm{a}$ & $52.26 \pm 7.2 \mathrm{a}$ & $52.35 \pm 8.3 \mathrm{a}$ \\
\hline
\end{tabular}

${ }^{(1)}$ Control, no supplementation with protected fat; Sup25, supplementation with $30 \mathrm{~g}$ per head per day with protected fat until day 25 of post-lambing; and Sup60, supplementation with $30 \mathrm{~g}$ per head per day with protected fat until weaning at day 60 of post-lambing. 
evidenced by the same trends on live weight and body condition among the treatments. Chikunya et al. (2004) showed that diets with $50 \mathrm{~g} \mathrm{~kg}^{-1}$ of fatty acids did not impair microbial activity in the rumen and did not alter the dry matter intake, although these authors observed an intense biohydrogenation of lipids.

The daily supplementation with $30 \mathrm{~g}$ of protected fat was not enough to allow significant increases on ewes live weights in the post-lambing period. This is in compliance with the results obtained by Son et al. (1994), who reported similar live weight gain for ewes supplemented with $40 \mathrm{~g}$ or less of calcium salt protected fatty acids in post-lambig. However, Appeddu et al. (2004) and Godfrey \& Dodson (2003) found a decrease on ewes live weight supplemented with protected fat in comparison to the control diet.

Ewes were cycling shortly after lambing (Table 2), which shows the potential of Santa Inês breed for accelerated breeding. The interval from lambing to first clinical estrus was smaller for treatment Sup25, in comparison to the treatment Sup60. However, they did not differ statistically from the control diet. The low values observed for all treatments could be due to ewes' exposure to rams on day 15 after lambing, and to lack of reproductive seasonality in Santa Inês ewes (Araújo et al., 2009).

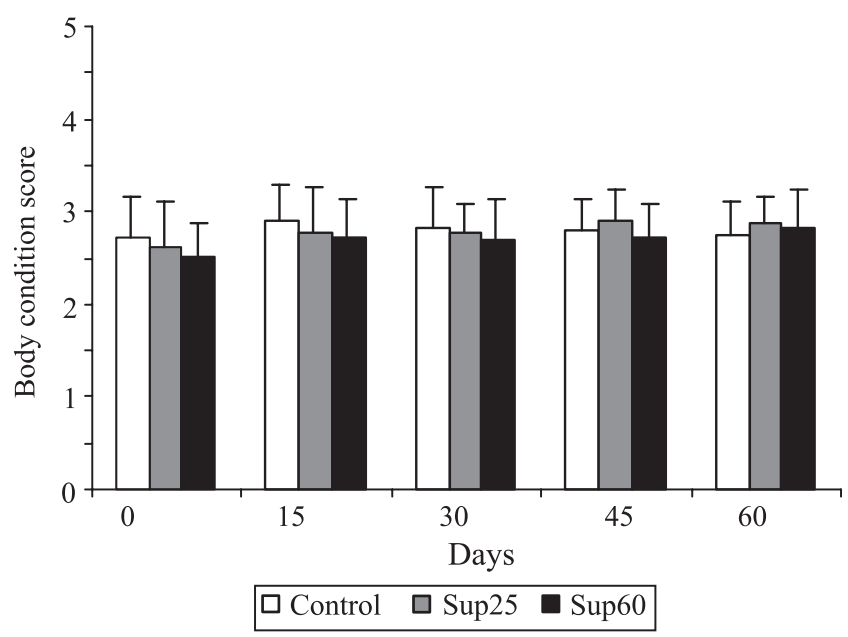

Figure 1. Means \pm standard deviations for body condition score ( 1 to 5) at lambing 0 , and at 15, 30, 45 and 60 days afterlambing for the treatments: control, no supplementation with protected fat; Sup25, supplementation with $30 \mathrm{~g}$ per head per day with protected fat until day 25 of post-lambing; Sup60, supplementation with $30 \mathrm{~g}$ per head per day with protected fat until weaning at day 60 of post-lambing.
According to Godfrey et al. (1998), ewes exposed to rams during the postpartum period are led to a reduction of uterine involution period with advancement of luteal function, higher concentration of progesterone, and earlier onset of estrus.

Intervals from lambing to conception were very short and similar among treatments (Table 2). The conception rate was not different among treatments and showed no improvement by the use of the protected fat as supplement to ewe's diets. The conception rates found in this experiment, between $72.22 \%$ and $78.95 \%$, can be considered high for the short period between lambing and next conception. Spicer et al. (1993) suggested that the increase in the conception rate could be the result of an increase in cholesterol concentration in plasma.

It was observed that up to 50 days of the postpartum period, more than a half of the ewes had already been mated and conceived in all treatments (Figure 2). Treatment Sup60 was always numerically superior to other treatments, though it was not significant. These results indicate that protected fat supplementation to ewes diet is not effective in reducing the number of days from lambing to conception nor in reducing conception rates, probably due to the plenty nutrition to which the ewes of all treatments were subjected.

The average number from postpartum clinical estrus to conception was not different among treatments (1.92, 2.43 and 1.73, for the control, Sup25 and Sup60, respectively). Eloy \& Sousa (1999) stated that the second estrus postpartum is considered the ideal for mating, due to a higher ovulation rate in comparison with the first postpartum estrus, and uterine regression (Hafez, 1995).

Table 2. Means \pm standard deviations for the intervals form lambing to first clinical estrus (ILFE) and to conception (ILC), and the conception rate (CR) for ewes under treatments of supplementation with protected fat ${ }^{(1)}$.

\begin{tabular}{llcc}
\hline Treatments $^{(2)}$ & ILFE (days) & CR (\%) & ILC (days) \\
\hline Control & $32.37 \pm 11.5 \mathrm{ab}$ & $72.22 \mathrm{a}$ & $45.23 \pm 11.4 \mathrm{a}$ \\
Sup25 & $27.23 \pm 8.4 \mathrm{a}$ & $72.22 \mathrm{a}$ & $46.54 \pm 10.4 \mathrm{a}$ \\
Sup60 & $35.45 \pm 15.3 \mathrm{~b}$ & $78.95 \mathrm{a}$ & $45.20 \pm 10.0 \mathrm{a}$ \\
\hline
\end{tabular}

(1) Means followed by equal letters do not differ by SNK test, at $5 \%$ probability. ${ }^{(2)}$ Control, no supplementation with protected fat; Sup25, supplementation with $30 \mathrm{~g}$ per head per day with protected fat until day 25 of post-lambing; and Sup60, supplementation with $30 \mathrm{~g}$ per head per day with protected fat until weaning at day 60 of post-lambing. 
There were no significant differences among treatments for lambing rate and lambing interval (Table 3). Lambing intervals were very short and showed the great potential of Santa Inês breed for lamb production, especially when comparing to wool breeds, which have marked seasonality and postpartum anoestrus. These results are in accordance with Costa et al. (2007), who showed a little or no influence of lactation anoestrus and seasonality on the return to postpartum estrus in Santa Inês ewes under different nursing managements.

There was no difference in number of born lambs per ewe before (1.4, 1.2 and 1.4, for control, Sup25 and Sup60, respectively) and after (1.57, 1.33 and 1.54 for Control, Sup25 and Sup60, respectively) the application of treatments. There was a trend of higher

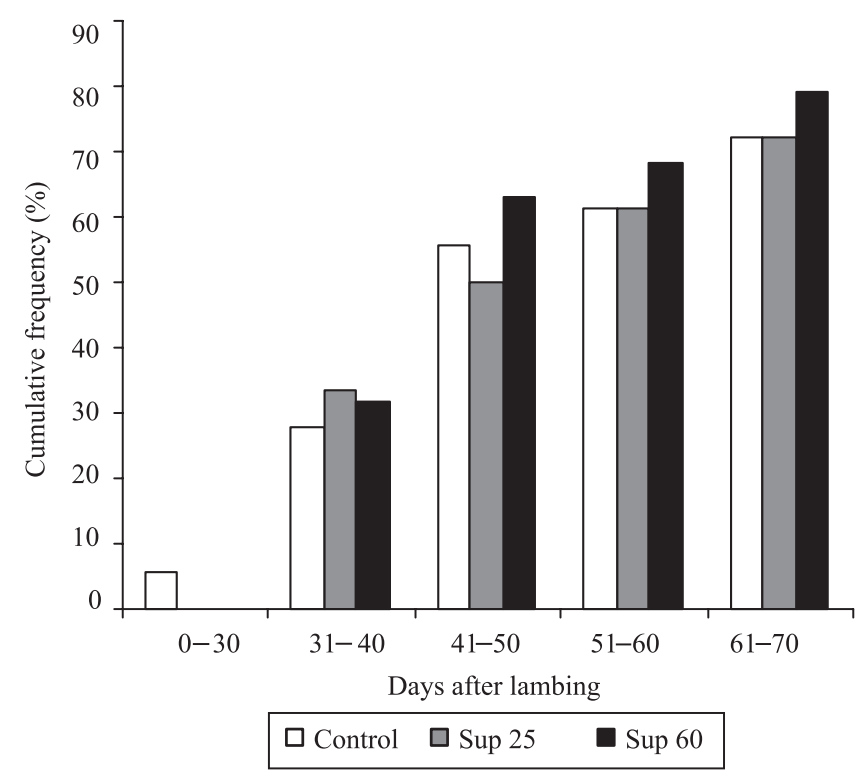

Figure 2. Cumulative frequency (\%) of ewes conceived after lambing with treatments: Control, no supplementation with protected fat; Sup25, supplementation with $30 \mathrm{~g}$ per head per day with protected fat until day 25 of post-lambing; Sup60, supplementation $30 \mathrm{~g}$ per head per day with protected fat until weaning at day 60 of post-lambing.

Table 3. Means \pm standard deviation for lambing rate and lambing interval.

\begin{tabular}{lcc}
\hline Treatment & Lambing rate (\%) & Lambing interval (days) \\
\hline Control & $72.22 \mathrm{a}$ & $195.15 \pm 10.7 \mathrm{a}$ \\
Sup25 & $70.59 \mathrm{a}$ & $198.00 \pm 10.9 \mathrm{a}$ \\
Sup60 & $77.78 \mathrm{a}$ & $196.36 \pm 10.3 \mathrm{a}$ \\
\hline
\end{tabular}

values after the trial, which denotes that ewes were well nourished.

Encinias et al. (2004) evaluated ewe's supplementation with linoleic-acid-rich seeds in the first 45 days of gestation and found an increase on prolificacy in comparison to the control diet. According to Muñoz-Gutiérrez et al. (2002), energy from diet can stimulate the foliculogenesis by means of alterations on the concentrations of leptin and diexoamine. According Downing et al. (1995), diets containing high levels of energy and protein can increase the ovulation rate in ewes with poor body condition score.

Higher prolificacy in ewes, after the trial (L2), might be due to the better nourishment to which they were subjected. From the first lambing (L1), ewes were kept only on pasture during the mating season and gestation, without any supplementation. On the second lambing (L2), dams were in lactation with a lower body condition score, but they were supplemented with silage and a concentrate mixture, which ensured a greater intake of energy during mating. It probably led to an increase on prolificacy.

\section{Conclusions}

1. Supplementation with protected fat does not improve the intervals from lambing until first clinical estrus and conception, as well as the conception rate and prolificacy of well-nourished Santa Inês ewes.

2. Supplementation with protected fat does not influence weight and body condition of well-nourished Santa Ines ewes.

3. The first Santa Inês postpartum estrus can be used for mating, with a high conception rate.

4. It is possible to use accelerated reproduction systems with intervals of 196.5 days and lambing rate of $73.5 \%$ for Santa Inês ewes.

\section{References}

ANNISON, G.; ILLMAN, R.J.; TOPPING, D.L. Acetylated, propionylated or butyrylated starches raise large bowel short-chain fatty acids preferentially when fed to rats. Journal of Nutrition, v.133, p.3523-3528, 2003.

APPEDDU, L.A.; ELY, D.G.; AARON, D.K.; DEWEESE, W.P.; FINK, E. Effects of supplementing with calcium salts of palm oil fatty acids or hydrogenated tallow on ewe milk production and twin lamb growth. Journal of Animal Science, v.82, p.2780-2789, 2004. 
ARAÚJO, R.C.; PIRES, A.V.; SUSIN, I.; MENDES, C.Q.; RODRIGUES, G.H.; URANO, M.F.; OLIVEIRA, C.A.; VIAU, P.; DAY, M.L. Postpartum ovarian activity of Santa Inês lactating ewes fed diets containing soybean hulls as a replacement for coastcross (Cynodon sp.) hay. Small Ruminant Research, v.81, p.126-131, 2009.

BENCINI, R.; PULINA, G. The quality of sheep milk: a review. Australian Journal of Experimental Agriculture, v.37, p.485-504, 1997.

BEZARD, J.; BLOND, J.P.; BERNARD, A.; CLOUET, P. The metabolism and availability of essential fatty acids in animal and human tissues. Reproduction, Nutrition and Development, v.34, p.539-568, 1994.

CHIKUNYA, S.; DEMIREL, G.; ENSER, M.; WOOD, J.D.; WILKINSON, R.G.; SINCLAIR, L.A. Biohydrogenation of dietary n-3 PUFA and stability of ingested vitamin $E$ in the rumen, and their effects on microbial activity in sheep. British Journal of Nutrition, v.91, p.539-550, 2004.

COSTA, R.L.D. da; CUNHA, E.A. da; FONTES, R. da S.; QUIRINO, C.R.; SANTOS, L.E. dos; BUENO, M.S.; OTERO, W.G.; VERISSIMO, C.J. Desempenho reprodutivo de ovelhas Santa Inês submetidas à amamentação contínua ou controlada. Boletim da Indústria Animal, v.64, p.51-59, 2007.

DOWNING, J.A.; JOSS, J.; CONNEL, P.; SCARAMUZZI, R.J. Ovulation rate and the concentrations of gonadotropic and metabolic hormones in ewes fed lupin grain. Journal of Reproduction and Fertility, v.103, p.137-145, 1995.

ELOY,A.M.X.; SOUZA, P.H.F. de. Reinício da atividade ovariana em ovelhas Santa Inês no pós-parto. Sobral: Embrapa Caprinos, 1999. 2p. (Embrapa Caprinos. Comunicado técnico, 50).

ENCINIAS, H.B.; LARDY, G.P.; ENCINIAS, A.M.; BAUER, M.L. High linoleic acid safflower seed supplementation for gestating ewes: effects on ewe performance, lamb survival, and brown fat stores. Journal of Animal Science, v.82, p.3654-3661, 2004.

GODFREY, R.W.; DODSON, R.E. Effect of supplemental nutrition around lambing on hair sheep ewes and lambs during the dry and wet seasons in the U.S. Virgin Islands. Journal of Animal Science, v.81, p.587-593, 2003.

GODFREY, R.W.; GRAY, M.L.; COLLINS, J.R. The effect of ram exposure on uterine involution and luteal function during the postpartum period of hair sheep ewes in the tropics. Journal of Animal Science, v.76, p.3090-3094, 1998.

HAFEZ, E.S.E. Reprodução animal. São Paulo: Manole, 1995. $582 \mathrm{p}$.
KINSELLA, J.E.; LOKESH, B.; BROUGHTON, S.; WHELAN, J. Dietary polyunsaturated fatty acids and eicosanoids - potential effects on the modulation of inflammatory and immune cells: an overview. Nutrition, v.6, p.24-44, 1990.

LUCY, M.C.; SAVIO, J.D.; BADINGA, L.; DE LA SOTA, R.L.; TATCHER, W.W. Factors that affect ovarian follicular dynamics in cattle. Journal of Animal Science, v.70, p.3615-3626, 1992.

MADSEN, L.; RUSTAN, A.C.; VAAGENES, H.; BERGE, K.; DYROY, E.; BERGE, R.K. Eicosapentaenoic and docosahexaenoic acid affect mitochondrial and peroxisomal fatty acid oxidation in relation to substrate preference. Lipids, v.34, p.951-963, 1999.

MUÑOZ-GUTIÉRREZ, M.; BLACHE, D.; MARTIN, G.B.; SCARAMUZZI, R.J. Folliculogenesis and ovarian expression on mRNA for encoding aromatase in anoestrous sheep after 5 days of glucose or glucosamine infusion or supplementary lupin feeding. Reproduction, v.124, p.721-731, 2002.

NATIONAL RESEARCH COUNCIL. Nutrient requirements of small ruminants. Washington: National Academy of Science, 2007. 362p.

SANTOS, L.E.; CASTILHO, E.A.; DESTRO, S.R. Parâmetros termopluviométricos da região de Nova Odessa, SP, no período de 1967 a 1976. Revista Brasileira de Zootecnia, v.15, p.57-65, 1977.

SAS INSTITUTE. SAS user's guide software. Version 6.08. Cary: SAS Institute, 1996.

SHORT, R.E.; ADAMS, C.D. Nutritional and hormonal interrelationships in beef cattle reproduction. Canadian Journal of Animal Science, v.68, p.29-39, 1988.

SMITH, W.L.; MARNETT, L.J.; DEWITT, D.L. Prostaglandin and thromboxane biosynthesis. Pharmacology and Therapeutics, v.49, p.153-179, 1991.

SON, K.C.; SEVERSON, R.F.; PAIR, S.D.; KAYS, S.J. Comparison of the sucrose ester fatty acid components in flowers and flower buds of three Petunia x hybrida Hort. cultivars. Journal of the Korean Society for Horticultural Science, v.35, p.617-622, 1994.

SPICER, L.J.; VERNON, R.K.; TUCKER, W.B.; WETTEMANN, R.P.; HOGUE, J.F.; ADAMS, C.D. Effects of inert fat on energy balance, plasma concentrations of hormones, and reproduction in dairy cows. Journal of Dairy Science, v.76, p.2664-2673, 1993.

THATCHER, W.W.; BINELLI, M.; BURKE, J.; STAPLES, C.R.; AMBROSE, J.D.; COELHO, S. Antiluteolytic signals between the conceptus and endometrium. Theriogenology, v.47, p.131-140, 1997.

Received on January 10, 2011 and accepted on May 4, 2011

Pesq. agropec. bras., Brasília, v.46, n.6, p.663-668, jun. 2011 